\title{
CRITICAL EXAMINATION OF TRADITIONAL WORSHIP SYSTEMS AMONG IGBO PEOPLE OF NIGERIA: STUDY OF AKPO COMMUNITY
}

\author{
Emmanuel C. Anizoba, Anthony Onyedika Onyeume, \\ and Oguejiofo C. P. Ezeanya \\ University of Nigeria
}

\begin{abstract}
Akpo traditional people worship God directly through a special ritual called Aja-eze bi n' elu sacrifice of the God/King that lives in heaven. The research aims to investigate traditional worship systems among Akpo people of Anambra state Nigeria, and also examines the religious-cultural implications of traditional worship of people. The study shows that Akpo people believe in the worship of divinities, such as the sun god which is active and assists the major deity in sending the worshipers' request to God. Other deities worshiped in Akpo include: Ala, Ancestors etc. The study adopts a qualitative phenomenological research design and descriptive method for data analysis. Personal interviews form a primary source of data collection while the secondary source includes library resources. The findings reveal that the objects of traditional worship of these deities and divinities include image status, amulet, palm fronds etc., and the traditional system of worship in Akpo also include sacrifice and offerings, pouring of libation, traditional sermon etc. aimed at establishing the co-existence between the supreme being and man. The research recommends among other things, that traditional mode of worship should be integrated into the Christian ways of worship for easy answering of prayer by the gods/God.
\end{abstract}

Keywords: tradition, culture, examination, worship, world-view

DOI: https//doi.org/10.3176/tr.2021.1.06

Received 24 May 2020, accepted 17 June 2020, printed and available online 10 March 2021 


\section{Introduction}

Worship is the spontaneous expression of man's experience of the Divine Being whom he considers to be the Ultimate Reality and the Determiner of Destiny. In African traditional religion, worship takes place in temples, shrines and groves. There are daily, weekly, occasional and annual worships. The daily worship is officiated by the head of the family or compound on behalf of the rest and consists of calling the names and praise names of God and that of the family divinity, while pouring libation. This is followed by supplications for protection and blessing for the day. The weekly ritual follows the same procedure but in a more elaborate form as many take part. The occasional or annual worship is much more elaborate. It involves the whole community, and it is an occasion for giving thanks and renewal of fellowship.

Worship in the context of Akpo traditional religion has not been fully explored; neither have the objects of worship among the Akpo been fully discussed. The Ikoro (wooden gong), for example, is the means through which the traditionalist consults the spirits during worship in Akpo. This is of great religious importance in the interaction between man and the spiritual world in Akpo traditional milieu. Not much has been written on the Ikoro as the research found out. Similarly, though the Igbo mode of dressing seems to be generally applicable in almost all traditional Igbo societies, in Akpo the modes of dressing of the traditionalists are quite unique since they believe that a mode of dressing also attracts the attention of deity/deities during worship. Hence in Akpo, the traditional dressing during the festival is the mpempe (a special kind of dressing) which covers the top half of the body and is always worn. This dress is highly believed among the traditionalist in Akpo to be the favorite of Akpo deities/gods. The traditional worship consists of liturgy which is the means of communion and communication with God. The main elements of traditional liturgy are invocation, the pouring of libation, offerings and prayers and then songs or music or both together with drumming and dancing. The Divine Being is addressed by names and attributes and invoked to attend worship. The libation consists of drink offering of water, palm wine or alcohol. This is poured on the ground or before the shrine or on the emblems of the divinity. The idea is that by performing libation the ground is softened and symbolically the way is opened for effective communion and communication with the divine being.

The offerings range from animals to fruits, depending on the occasion of worship. In Igbo traditional religion, the commonest offering is the kola-nut and water. The Divine Being is invoked to come and eat kola nut, then the ancestors are also invoked to do the same. The kola-nut is then broken and cast on the ground and according to the rounded or flat surfaces that fall upwards, so the day will be lucky or unlucky. This is repeated several times till a positive response is obtained. Then one piece is put on the shrine and the other eaten by the worshiper or worshipers. Mbiti (1975: 54) stated that in the prayers that follow the offering, the needs of the devotee are put forward before the divine being. The worshiper is presented at the altar by the priest and is made to kneel and make his petitions, which are then repeated by the priest to the divinity for onward transmission to God. In Akpo, for example, the supplicant stands while he makes his petition and drink offering is all 
that is required. Prayer of course is not confined to sacred places, but anywhere and at any time an individual feels the need to communicate with the divine being. In all cases the attitude is one of reverence and respect. The song as a rule does not occur in all worships, especially at the daily and other private occasions, but mainly in public and annual events. The songs are then accompanied by drumming, handclapping, dancing and merriment. In all these things the devotee expresses his joy before the divine being. The invocations and prayers reveal the names and attributes of God and the divinities. As Ilogu (1985: 49) rightfully said about the Igbo, the confidence and hopes of the people, their belief in and sense of dependence on the divine beings to supply the needs of man and the fact of general relationship between God and men are made evident through worship. In Akpo, this dependent relationship on divine beings is expressed and enhanced through worship.

The study shows that Akpo people traditionally worship various divine beings and have a lot of objects of worship to this effect. In this regard, the current research is geared towards a critical analysis of Akpo worship system from a religiouscultural perspective. This approach has not been explored in the context of Akpo traditional religion by previous researchers. The study will no doubt help the Nigerian Ministry of Education in the area of curriculum development in Tertiary Institutions, secondary schools and primary schools as the case may be. Again, students of African Traditional Religion (ATR) who may wish to embark on a similar topic will consider the work very useful. It will also document the cultural changes among the Akpo people since the advent of Christian missionaries. Traditional religious worshipers in the area, who still hold the beliefs and practices in a high esteem will also benefit from this study, in order to learn about the areas they need to adjust. The study adopts a qualitative phenomenological research design and descriptive method for data analysis. Personal interviews form a primary source of data collection while the secondary source includes library resources.

\section{Operational definition of terms}

Traditional - the handing down of information, beliefs and customs by word of mouth or by example from one generation to another without written instruction.

Examination - an orderly attempt to test or obtain information about something, often something presented for observation.

Worship - the act of showing respect and love for a God especially by praying with other people who believe in the same god: the act of worshipping God or a god.

\section{The Akpo worldview}

Like most of Igbo communities, Akpo has a lot in common with other traditional societies, even though certain cultural traits still slightly distinguish them from other cultures. These traits form part of the bedrock for their uniqueness when compared with the Igbo people, and they include dressing, title taking, marriage, food, 
childbirth/Naming Ceremony, death and burial rites ceremony and Ikoro (Okafor 1992: 26). Therefore, the Igbo world view includes: belief in spirit, belief in magic and medicine, ancestral curses, among others. It is also believed in Igbo cosmology that there are some mystic forces in the universe which can be tapped and utilized to bring about some effects, good and bad Omoregbe (1999). Omoregbe observed that some people have got access to these forces (supernatural powers) and make use of them. Some use them for good purposes, such as healing and solving difficult problems of mankind, e.g. priest-physicians. Many people, however, use these powers for evil purposes, such as causing harm and disease to other people.

Omoregbe (1999) maintained that some people who have got access to these forces use them

to cause mysterious sickness and disease such as swollen legs, strokes, madness which sometimes leads to untimely death of the people involved. These may be witches and sorcerers who cause a lot of havoc by means of mystical forces. In this regard, Igbo Traditional conception of causes of diseases and sickness is always tied in to some gods, divinities or often spiritual forces. Equally, humans can also manipulate some forces to cause diseases or sicknesses for their fellow humans (p. 10).

\section{Childbirth/naming ceremony}

The birth of a baby in a family ushers in a long period of intensive post-natal care (Omugwo) for the baby and the mother. Onyebuchi (2010:16) asserted that in Akpo, the new mother is exempted from every form of work except breastfeeding her baby. For the young child and the mother, the provision of adequate food during pregnancy and lactation and the provision and promotion of the breastfeeding are the most essential needs. In agreements, Onwuneme (2001: 31) noted that in addition, her food consists of hot, peppery, sumptuous soup with lots of fish and spices like utazi, ehuru, uzuza and uda. Hot food is believed to be good for the cleansing of the stomach. She is bathed and her stomach is massaged with hot water regularly to reduce it and return it to normal size.

The nursing of the navel stump to heal properly (otube ida), circumcision (ibe Ugwu), naming ceremony (Igu afa) and tear piercing (ikpopu nti) for the girls are landmark events in this period of omugwo. Some families use the fallen of navel stump to plant tree crops like bread fruit, coconut or mango as a symbolic mark of the child's growth and development (Okolugbo, 2004: 33). Ezeanyaegbu (1998: 26) opined that certain dedication rites (igo ofo ani, igo ofo omugwo) would be performed during which the baby's forehead is made to touch ground before the name is announced, thereby, formally welcoming the child into the world and the family. It is a form of the dust to dust, earth to earth ritual, an acknowledgment of the earth as the primacy of the creation and the source of all life and sustenance. Some of Akpo names include: Chukwudi, Chukwuemeka, Chukwunyenum, Onyeike, Onyedikachukwu, Chinagorom, Chukwulota, Chukwubunna, Onyebuchi Onyebueke etc. 


\section{Marriage}

Marriage is the union of a man and a woman (inu di na nwunye) from different families with the consent of the partied and their parents. Marriage is indispensable for the continuity of the family lineage. Children occupy a pivotal place in the institution whose primary function is procreation and self-perpetuation. Akpo society is patriarchal. Invariably, men initiate marriage. According to Benedict Umeh (Oral interview, 2015) there are different forms of marriage in Akpo. Child or infant betrothal (obele) was one form. A man signifies his nuptial interest in a very young girl, sometimes a mere infant. If the parents of the girl agree, the girl was brought up in her parents' home in the knowledge of the relationship charted for her by her parents or even grandparents. The second form of marriage in Akpo is called consensual marriage. This is where an adolescent male tells his parents to search for a suitable wife for him or declares his intention to marry a named girl of his choice. The parents embark on an inquiry (iju ese) into the genealogical antecedents of the girl of his choice with a view of ascertaining whether she has a blemish-free background. If the parents are satisfied, the weeks preceding the marriage would be tutorial lessons (marriage interview/course in Christian theology) where the bride receives lessons and admonition on how to be a good wife and mother. The third form of marriage according to Chukwuma (2000: 16) is the (Ntutiyi Obele) though it is now obsolete and becoming extinct in the Akpo community. It is a form of marriage whereby a man with only female children from his marriage who is past the age of childbearing may permit one of his daughters, usually the eldest, to remain in the family home, have affairs outside and bear children who would bear their father's name and keep the lineage.

\section{Death and burial rites and ceremony}

Akpo people hold their dead in high esteem. Death is not the end of existence but the transition from this mortal terrestrial world to the spiritual realm of existence. They believe in life after death. The mourning of the dead is an occasion for kin and other survivors to revive their ties and exchange memories, a time when life seems most vivid and desirable. When a person dies, it is not only the family of the deceased that feel the loss, the entire community does. There is widespread weeping and wailing especially among the relatives and friends (ikwu ni ibe). Sorrow, like laughter, is a universal language and so women and children weep openly and disconsolately while men wear forlorn, sepulchral faces. The dignity of manhood limits his tears to his heart ( $A k w a$ nwaoke di ya na obi). The initial formal response is to arrange for the first burial (ikwa ozu), which is the physical interment of the corpse. Each community has a cemetery (ebe ana eni ozu) where corpses (ozu) are buried. Some communities have a separate cemetery for children. Physical burials often take place in the early hours of the afternoon. A forerunner goes before the pallbearers waving fresh yellow palm fronds, warning people to turn away their 
faces from the offensive sight of the corpse as they lead the corpse to the cemetery.

However, the culture of burying adults in the cemetery is gradually fading away, in Akpo people now bury their dead in the house or in an open lawn and spaces adjourning or abutting the house. Suicide victims are not buried in the house but are shoved into a sack and dragged on the ground to the evil forest and dumped for wild beasts to devour. Ogbukaonyeike (Oral interview, 2015) briefed the researcher on the essence of burial - to give the dead a smooth transition to another life and be formally ushered into the new realm of existence (Ani muo) as the ancestral spirit (Ndi muo). Until this is done, the deceased is now a full citizen of the ancestral world. He said that spirit of the deceased is believed to be restless until this burial is completed, and it will not be able to extend its blessings and protection from the world beyond to its relatives, it may even turn to hunt them (Onyeike, 1982: 17). Thus, the burial among the Akpo is akin to the theological position and implications reminiscent of the Christian doctrines of the communion of saints, prayers for the faithful departed, heaven and purgatory.

\section{Title-taking}

Title-taking is typical in every community in Akpo. Titles are held in high esteem as some are given according to age bracket as well as personal and remarkable achievements. The highest title in Akpo is Ezechikelu which is given to anyone in the community who attends the age of 90 . He is meant to hold the title until death then another person within that age bracket takes up the title. He is the custodian of the tradition in that particular village or community. The next age-tagged title is the Eze Chidiebube which is at the age of 85 and above. Ezechiedo is the third highest title in Akpo which is at the age of 78. Apart from these three titles, every other villager, irrespective of their age bracket, can be bestowed with the title Ogbu-ewu, Ezeigwe and Ezemma.

\section{Dressing}

The identity of the Akpo was best expressed through their dress code. This is because the dress of an individual the very first contact one makes with the person, even before any word of greeting is exchanged. Onyeike (2000:2) affirmed that the pre-Europeanized Akpo dressing (ekike) was in the form of a hand-woven loincloth or calico called Akpukpo for women, une for young girls and mpempe for men. Hence, like their counterparts from the Igbo, Hausa, Yoruba and Ijaw extraction, it is possible to identify them by their dress sense, although it is becoming more difficult to do with the Akpo because of the advent of Christianity and westernization. 


\section{Akpo traditional worship systems}

Akpo people worship God directly through a special sacrifice called Aja-eze bi n' elu sacrifice of the God/King that lives in heaven. According to a native doctor, Chief Benedict Umeh from Ogbo said that Akpo people believe that God is so perfect and needs nothing from such a low being as man. Again, because many divinities, spirits, or gods are harmful, they feel like appeasing, placating and pacifying them. For these and other reasons, worship is given to divinities and spirits on behalf of the supreme God on a general note, God Chineke/Chukwu remains the object of worship among the traditional Akpo people.

Awolalu and Dopamu (1979: 121) have stated that:

Among the Igbo, it is true that there is no status or images of chukwu. But sometimes, symbols are dedicated to Him. Many homes have shrines dedicated to chi the guardian angel, and to other tutelary divinities. Where we have such shrine, a symbol mostly a cotton plant, is dedicated to chukwu, the supreme deity. In some places, there are bottles buried up to the neck. And at the time of planting, palm-wine is poured into the circle of bottles as an offering to God.

Awolalu and Dopamu conceive the supreme being/deity (chukwu) as an object of worship among the Igbo even though his images or status does not exist. Other spirits or deities they worship are intermediaries between the people and God. This structure of religion had made scholars, especially the early foreign writers to see the religious life of the holistic Africa as polytheistic.

\section{Akpo traditional sacrifices/offering (thanksgiving)}

Sacrifices/offerings always go with prayers and petitions. This relationship between sacrifice and prayer makes them equally important to the people. But when the need to worship becomes pressing, prayer alone does not help matters, and sacrifice becomes fundamental. Sacrifice is a source of supplicating, propitiating, thanking, and appeasing God/gods. Sacrifices are offered to thank God or gods for his goodness to the worshipers. Ajayi (1981: 94) asserts:

The Igbo do not offer frequent sacrifice to God because they believe that God is good but the spirits are evil. God harms nobody but the spirits do because they flare up easily if they are neglected. So sacrifices are offered to the spirit to appease them and avert evil. Some of these evil spirits are non-human as earlier said but most of them are the spirits of the dead. Evil spirit represents sacrificed persons, those who die prematurely without children, people who were verse in crime and wickedness, woman who died in childbirth and so on. Spirits of the ancestors who died at the old age, who were honoured while on earth are highly revered at death and their spirits are regarded as good ones who oversee the activities of those 
they left behind. Sacrifices are offered to them to appease them to keep them in place of perpetual contentment. To neglect them is to incur their wrath.

From what Ajayi is saying, sacrifices are used to prevent evils or calamity from be falling individual and societies. In some cases, even when there is no sign of danger, sacrifices are means of making the spirits not to feel neglected. They are appeased through sacrifices. In all, it could be agreed that sacrifices help in putting the society in order. The traditionalists once in a while thank God with sacrifices for His good will. According to Mbiti (1975: 63-64) the kind of situation that calls for sacrifices may include drought, epidemics, war, raids, calamity, insect pests and destructive floods. Since these affect the community, it is the community which then sacrifices an animal. Such animals are carefully chosen to make sure that they are acceptable to God. Usually, they have to be of one color, which may be black, white, brown and if they are domestic animals they have to come from an honest owner. Wild animals are also sacrificed for personal and family needs, such as health, marriage problems, remembering the departed, or requests for prosperity or success.

\section{Traditional libation}

Libation is usually accompanied with prayers. Quarcoopome (1987: 35) writes that an Akan libation prayer, for example, begins with this tribute to God, the dependable God and friend, the benevolent, whose first nature is virtue in the prayers which follow the libation, the needs of the worshipers are expressed, and the divine being sought to satisfy them after pouring libation, prayers follow immediately not only among the Akans, but among the Akpo people. The people tenaciously hold to the belief that the act of pouring libation softens the land for free interaction and movement between the spirits and the worshipers. That is to say, libation paves or prepares the way of interaction and movement of the spirit from the spirit world to the human world in the act of worship. The substances for libation are usually liquid which can be water, wine or liquor.

\section{Sermons}

Sermon is not very common in traditional religion. There are no written documents about it. The lessons on human behavior, punishments, and rewards are contained in their pithy sayings, songs and dances, proverbs, folktales etc. On some occasions the traditional worship calls for delivering of sermons. Once in a while, a sermon in the traditional worship occupies a very important place in maintaining and uplifting of peoples' moral consciousness. Okafor (2001: 9) said that:

... During worship, as the priest officiates, he would warn against embarking on or committing some notable evils as against the will of gods, a worshiper who is there present might out of showing remorse for his 
wrong doings, confess, pledge or vow to offer or bring sacrifice to calm the anger of the gods.

Okafor meant that the traditional sermon fosters confession and repentance. It can make an adherent to confess and repent from wrongdoings. In a sermon, much information about past happenings is used as examples: these references make an adherent to always recall the consequences and benefits that might be accrued from every act in his/her life. A sermon also enhances the spirit of motivation for every worshiper. A worshiper becomes motivated with what he expects to gain in abiding by the contents of a sermon.

\section{Traditional songs and dances among the Akpo people}

Through music, singing and dancing, Akpo people are able to participate emotionally and physically in the act of worship. Traditional music and dances can make a devotee attain spiritual satisfaction during worship. The traditionalists participate well in the act of worship. The traditionalists participate well in the act of worship with the help of music, songs and dances. The sound of music, the worshippers are informed about the commencement, and other stages in the act of worship. It is believed among the Akpo people that the spirits are kept alert at the sound of religious music. Religious music, songs and dances therefore alert the spirits. Okpala Chukwuka (Oral interview, 2015) briefed the researcher on the importance of songs and dances in the village. He said that music raises the worshiper from an ordinary state to a state of ecstasy. The influence of music can make a devotee promise to sponsor a future gathering of worshipers. The traditionalists believe that songs and dances can relieve sick worshipers from pain, and sometimes they are healed. Songs and dances provide physiological and psychological relief. Most of the traditional religious songs and dances convey people's perception of life. The songs and dances contain the traditional history of the people's relationship with the unseen world, the heroes and heroines, renowned men and women, failures, progresses, lessons, God's/god's favor or wrath are the contents of the religious songs and dances.

\section{Akpo traditional festivals}

Akpo traditional festivals are annual gathering at which the whole community meets to give thanks to God, the divinities and the ancestors. Akpo traditional festivals are agricultural festivals and are held to mark the end of one agricultural year and to welcome the beginning of another. It is an occasion to honor the divinities and the ancestors as intermediaries of God for a successful agricultural year and to pray and hope for another glorious year. The yam and cassava are the most important agricultural products celebrated at this period. In some cases, the festival is regarded as the divinity's birthday. The ceremony: before the date of the festival is fixed the oracle is either consulted about the exact date or the traditional priest and his assistants 
decide on the date. The final date is announced to the people so that they can make the necessary preparations. Animals such as cows, sheep and rams are offered as well as yams, rice etc. (usually the first produce of the farm). The festival which may last from a week to one or two months is heavily patronized by the people. They put on their best clothesapparels and offer sacrifices and prayers. Some of them are present at the slaughtering of the sacrificial animal at the main shrine which takes place early in the morning to mark the beginning of the whole ceremony. Through the festivals, Akpo people remember the ancestors to their help and protection as well as abundance of food, good health and prosperity. This dependence on the ancestors is that they are believed to act as intermediaries between the living members of the community and God/divinities. The festival is also an occasion for the renewal of fellowship between the living and the dead. It may also be used as a propitiatory ceremony for the ancestors where calamity has occurred.

\section{Findings of the research}

The traditional worship in the people of Akpo brings out some elements of their culture. Worship provides succor and solace for the members of the community. The worshiping community fosters or enhances solidarity welfare for its member through worship. Every worshiper believes that sooner or later, he or she benefits from the act of worshiping God/gods. According to Obodo Dominic (Oral interview, 2015), from Amaife, worships assist the traditional society in promulgation and execution of laws, norms, customs, and ethics of the society. Among Akpo, the people had no regulatory order of government or headship other than the God or the gods of the land. Every human problem is solvable basically by the supersensible reality, be it agricultural, economic, social, health-related, intellectual, political, administrative problems or otherwise. All these problems are presented to God in worship. In the political or administrative sphere, they admit the Igbo Enwe Eze syndrome. Today, man and God/gods rule the contemporary traditional society, yet the gods are consulted in the worship. Health problems are presented to the gods especially by the traditional religious leaders like the priests, diviners and medicine men in worship and rituals.

Rituals on their own are forms of worship. The function of ogwu prepared with rituals has been acknowledged by Adibe (2006: 45) as he accepted that ogwu could be used to put the human body in order; it could be said that worship brings good health. It is believed that it is the spiritual powers contained in rituals that determine the efficacy of the ritual. On the social sphere, during the wars, the diabia prepares ritualized $o g w u$ for victory, treatment or prevention of injuries etc. Some are kept at homes, farms, palace, on the body etc. In preparation of the traditional ogwu, the traditionalist invokes the ogwu (medicine) divinity and the Agwu divinity-the lord of divination. Ekwunife (2003: 16-17) adds:

Religious rituals unite people's beliefs and sentiments channeling them to their primary source of being. The transcendence. They have the inherent quality of giving meaning to the contradictions that can only be adequately 
resolved in transcendental otherness. Thirdly, rituals reveal the social values of the religious community communicating them to participants. Fourthly, rituals manifest the structure of community, the hierarchy of beings in it, the rights and obligations of the members as well as their mutual dependence on each other and on transcendental realities. Fifthly, through rituals man's daily activities as well as his cosmos are sanctified so that he becomes on with all realities.

Ekwunife propounds five points in explaining the importance of rituals in the study of religion. In fact, it is difficult to separate the importance of rituals propounded by Ekwunife from the importance of worship. As far as religious rituals form part of the worship exercise, worship as the canopy under which they lie, conveys every importance found in rituals. Certainly, worship in some cases prompts festivals. Some religious activities (worship) are done in honor of the existence of certain god(s), as the votaries or adherents plan to make such (worships) religious activities laudable, they see themselves feasting a festival, and such a feasting occasion becomes instituted as festival. Onwubiko (1991: 45) states that the Olympic festivals were celebrated in honor of the Olympian gods. Onwubiko points out here that festivals can be carried out in honor of the gods as in the case of the Olympian gods in Athens. If the people become weak, worship enabled to correct a festival's mutations. Many traditional festivals expired because the leading traditional practitioners and worshipers are converted to other religions. In some cases when some active practitioners die, the few practitioners available always lack the numerical and spiritual strength to resuscitate the festival. Therefore, traditional worship keeps some festivals in Akpo alive. During worship, the ancestors and their spirits are venerated. The good and emulating lives of the ancestors are emphasized in worship. Their live attainment as heroes and heroines are appreciated in worship and worshipers' struggle to achieve such regard. According to Mr. Okpala Chukwuka (Oral interview, 2015), a farmer from Agbaelu, the ancestors are believed to be watching over activities of the living, because of the responsibility of the ancestral cult, people live a more careful life to escape or avoid being a victim of the ancestralinflicted misfortune. In that case, worship (traditional) could be said to build the spirit of encouragement and emulation, as well as a spiritual conscious life. Also worship in which the ancestors are held in esteem helps in actualizing the respect for the elders because they are believed to be spokesmen between the masses and the ancestors and the future possible ancestors. In Akpo, at death the stages of worship organized for the deceased passed information about the time of death, burial and the final burial rite and times for subsequent common orations. Apart from death, stages of worship in the year inform the less intelligent traditionalists who do not know the moon count, the seasons and programs of the year. In that regard, worship can be deemed as a timekeeper to some traditionalists. Equally important are the following elements of worship: prayer, sacrifice, libation, blessings/invocation/thanksgiving/ salutation, sermon and songs and dances.

In Akpo, Ikoro is a traditional gong or drum used in summoning people in times of dire emergencies like war. Its sounds portend ominous danger and a call to duty. It 
is therefore not sounded in vain. Ikoro literally means 'when the event necessitating the sounding of emergency alarm occurs'. It is a festival marking the readiness to answer the call of duty in time of imminent danger. Ikoro festival is a war festival meant to prepare male youths for adverse situations, so as to inculcate the ability to endure hardships (Onyebueke, 1996: 10). After the preparation in the shrine and flogging new inmates to welcome them by the senior members, a forerunner joins the wrestlers in dancing before breaking an egg in the venue as a way of preparing the ground and announcing the actual start of the festival (Onyeike, 1982: 18). Mothers sometimes bring their infants to be flogged. Parents are proud of sons who participate in the festival; those who do not are considered chicken-livered, booed and shunned by parents. To avoid this embarrassment, such persons would secretly self-inflict sharp injuries on their bodies to give impression it was sustained in the course of the festival. The festivals afford marriageable girls the opportunities to identify strong, brave young men at whom they could make subtle passes as potential suitors.

During the festival Ekeakpara giant masqueraders appear brandishing ancient, larger than life traditional weapons like the ceremonial sword and dane guns with a port from which smoke rises as it balanced precariously on the masquerader's head. Men carrying large basins, baskets and wielding guns signifying war refugees engage the masquerader in mock battle. At the end of the ikoro festivals, both camps come together in the courts of the palace of Nnuata to eat from boiling cauldron of rich porridge with their bare hands. This shows manliness. They later take their bath in a stream whose water is believed to have medicinal, curative effect on scratches and wounds of lacerations sustained during the flogging.

Among the Akpo people, the morning rituals begin with invocation: Chukwu (Deity) come and eat kola-nut; Ala (Earth Goddess), come and eat kola-nut; Ndiche (Ancestors) come and eat kola-nut. The ancestors are the guardian of the living family, so men approach them more than gods in their daily needs. Libations are poured to the dead and part of food at each meal is given to them before eating. They are regarded as the 'living dead'. Belief in their continued existence and influence on those they left behind is very strong in Akpo. The ancestors are not only revered as past heroes but are believed to be present watching over the household and directly concerned with the fortune and misfortune of their family. The ancestors according to Ugwu and Ugwueye (2004: 66) are pristine men and women who originated from the lineage, clan or ethnic group and who provide the people with their identity. They are believed to be the custodians of the laws and customs of the tribe and prepared to punish those who infringe upon them.

Both the ancestors and the divinities live in the world of spirits. Spirits are thought of as powers which are abstract but take the shape of human beings. They are so constituted that they wish to be 'seen'. They appear abnormally tall, fat or thin. More often than not, they take the form of the place of their abode. Spirits according to Akpo people belief are everywhere. It is believed that every object or creature has its own spirit. The Akpo people believe that the 'Iroko' tree has its own spirit. It is in this vein that one can agree with Mbiti (1969: 17) when he says that there are categories of spirits. We have ghost spirits. Akpo people believe that a person whose dead body 
is not buried with correct rites will not be allowed to go to the abode of the departed blessed ones. Spirits are a great reality in Akpo. They are regarded with great fear. It is believed however that human beings can bargain with them or control them with magic. Akpo people believe that God is the absolute controller of the universe. God created the world and put man in it. God is unique to the people of Akpo. Whatever power and authority there may be, they exist in consequence of God who is the ultimate fountain head of all powers and authorities. The divinities are entitled to their names because their beings are derived from and dependent upon deity.

In Akpo the major spirits are: Earth goddess, Hill deity, the marine spirits - ndi otu/ndi mmiri and ancestral spirit Ndi-ichie (the living dead spirits). The minor spirits include: the sun god (anyanwu), god of the wilderness (chi bi n'agu) translated as the spirit that lives in the wilderness or bush, the representative of creator-God (chukwuokike) translated as mother god representing the creator God-chineke or chukwu, and nature spirits (especially plants) and the god of medicine, healing and mental conditions (ogwu/agwu). Earth Goddess: Earth goddess is regarded as God of the land and mother of fertility. Onwu (2002: 21) has stated that the earth goddess has an enormous influence on the Igbo, and that the Igbo have abandoned the worship of Chineke (God) to the worship of the Ala-Earth goddess and other created divinities. They see these gods as messengers of the creator-God. In many religious-cultural areas of Igbo land, earth goddess is highly regarded. Almost every community has its own earth-goddess. In Akpo there are many earth goddesses, but the most influential ones are: Oganachi, Onyebara, Ekeapara Udeakwa, Chiebenuzo, Akpukpochereobu, Oganachi etc.

Earth-goddesses are very strong in Akpo. They are believed to be the owners of the land. When an atrocity is suspected, for the earth-goddess to be able to trace the culprit(s), every member of the community is expected to walk barefoot. During worship of any spirit of the land, worshipers move or walk barefoot. The worship of an earth-goddess is always expensive. It involves offering animals, food, drinks, clothes and money. Earth goddess in Akpo does not have specific days of the week for their worship. The priest fixes the days of worship.

Hill deity: This is regarded as the god of the hills that surround the land and other vegetations of the human environ in the Akpo land. Ifesieh (1989: 33) says this about the mountain:

In Africa, certain religious beliefs, myths and legends are associated with some of the hills and mountains. Thus, a group of people living around these particular physical features set them apart for religious worship. Rituals, sacrifices, offerings and prayers may be made facing the mountains and hills, or at their foot. Community religious leaders usually keep these places clean.

Each of them believes that mountains and hills are abodes of spirits, and worships take place on or at the foot of mountains or hills. In Akpo, such belief exists, but the worship of hill-deity/spirit is organized at the plain, where its shrine is built. The hilldeities that exist in Akpo includes Nwangwo and Obuakwa. 
Ancestral spirits - Ndi-ichie (cult of the living dead). These are believed to be the spirits of the dead members of the community who lived an exemplary life without stain. Quarcoopome (1987: 128) opined that:

"The ancestors were the souls of the departed heroes and heroines of the various west African tribes. Belief in the ancestors is based on the general notion that life continues after death and communion and communication are possible between those who are alive here on earth and the deceased. The ancestors are believed to have power to influence the affairs of the living for better or for worse".

He further writes:

Accordingly, we can distinguish three classes of ancestors, since old age is regarded as a blessing given to those who keep the laws and traditions of the community; anyone who died in grand old age is ranked among the ancestors. And there is a third class, which could be called the class of the anonymous ancestors. They did not make any distinguishing mark on the community but had not caused any great harm either. They form great mass of the ancestors, who, when food offerings are made libations are poured to the ancestors, without calling their names, received their own share.

In the context of Akpo traditional religion the above applies. This is why the ancestor spirits are crucial to the wellbeing of the people. In Akpo, worship is also organized only on Nkwo and Orie days, when it is believed that the ancestral spirit is most active. The minor deities/spirits that are worshipped by the people are the sun god (anyanwu), god of the wilderness (chi-bi n'agu) translated as the spirit that lives in the bush or wilderness. The sun god - (anyanwu) is believed to be the god that provides light, vision and sight to the adherents. According to Onunwa (2005: 209):

The 'sun' is one of the most powerful agents of the Supreme Being it is believed to inhabit the sky with chukwu. The relationship between the sun and chukwu is not fully comprehended as different people emphasize it in different ways. The sun is said to be an emanation of the Supreme Being or a reflection of his glory and splendour.

Akpo people believe the sun god is active and assists the major deity to send the worshiper's request to God. The god of the wilderness (chi bi n'agu) - is the god in charge of the people's affairs in the wilderness where they plant food, hunt for animals and where the villagers can take refuge. The god of medicine, healing and mental condition: The god of medicine (chiogwu) is the god that takes care of healing, medical provisions and mental conditions of adherents/communities. 


\section{Recommendation}

1. In the traditional settings of Akpo societies, worship should be refined into a higher decency.

2. Akpo traditional religious experts have to rise to their vocation, prepare a liturgical and universal uniformity of the traditional Akpo religious worship systems that should be contained in doctrinal books which can serve as holy books for a religion.

3. A general festival period for at least the communities of the Akpo must be introduced like the Ekeakpara (Ufiajioku) which can be given a particular date throughout Akpo land.

4. The traditional worshiping community/communities ought to form organizations just as the Christians have the Christian Association of Nigeria (CAN).

5. Worship days should be mapped out at least for each community, like the Christians worship on Sunday and Islam worship mainly on Friday.

6. Akpo traditional religion must help the children growing up in rural areas to acquire traditional and informal education.

\section{Conclusion}

Traditional worship in the context of this research work is shown as man's response to the appearance of the Holy, that is, to the sacred, transcendent power of being. The research showed that in Akpo traditional religion the normal mode of response and assent to the unique Holy include all kinds of cults, rituals and liturgies, prayers, songs and dances. Akpo people worship God directly through special scarifies called Aja-eze bi n' elu, sacrifice of the God/King that lives in heaven. The research demonstrated that Akpo people believe in worship of divinities like the sun god which is active and assists the major deity in sending the worshipers' request to God. Other deities worshiped in Akpo include: Ala, Ancestors etc. The objects of traditional worship of these deities and divinities include images, status, amulet, palm fronds etc. As the work showed, traditional worship among the Akpo include sacrifice and offerings, pouring of libation, traditional sermon etc. All are meant to attract the attention of deities and divinities in Akpo, and also to consolidate the vertical relationship that exists between deities and divinities and the people of Akpo.

Addresses:

Emmanuel C. Anizoba,

Department of Religion and Cultural Studies

University of Nigeria, Nsukka

Postcode 410001

Nsukka, Enugu State, Nigeria

E-mail: emmanuel.anizoba@unn.edu.ng 
Anthony Onyedika Onyeume

Department of Religion \& Cultural Studies

Faculty of the Social Sciences,

University of Nigeria, Nsukka

Nigeria

E-mail: onyeumeanthony@gmail.com

Oguejiofo C.P. Ezeanya

University of Nigeria, Nsukka

Nigeria

\section{References}

Adibe, G. E. (2006) The complex features of Igbo traditional Ogwu: analysis and interpretation. Onitsha: Good Mark Prints Production Inc.

Ajayi, A. (1981) 50 Q/A on West African traditional religion. Ado Ekiti: Omolayo Standard Press and Bookshops Co. (Nig.) Ltd.

Awolalu, J. O. and P. A. Dopamu (1979) West African traditional religion. Ibadan: On, Boneje Press and Book Industries (Nig) Ltd.

Chukwuma, E. C. (2000) Festivals and marriage in Akpo. Lagos: St Jame's Publisher.

Ekwunife, A. N. O. (1999) Meaning and function of "ino uwa" (reincarnation) in Igbo traditional religious culture. Enugu: SNAAP Press Ltd.

Ezeanyaegbu, A. (1998) The Igbo culture and Christianity. Lagos: St. Anthony Publishers.

Ifesie, E. I. (1989) Religion at the grassroots. (Studies in Igbo Religion.) Enugu: Fourth Dimension Publishing Co. Ltd.

Ilogu, E. (1985) Christianity and Igbo culture. Onitsha: University publishing Company.

Mbiti, J. S. (1975) Introduction to African religion. London: Heinemann Educational Books Ltd.

Okafor, B. N. (2001) The philosophy of religion. Obosi: Olu Books and Bible Publishers.

Okafor, E. A. (1996) The history of Anambra. Onitsha: Emeka Educational Publishers.

Okolugbo, E. O. (2004) History of the Ukwuani and Ndosumili people of the Niger-Delta. Benin: Ethiope Publishing Corporation.

Onunwa, U. R. (2005) Selected themes in African religion and culture. Umuwulu-Obosi: Pacific Publishers and Pacific Correspondence College Press Ltd.

Onwu, E. N. (2009) Uzondu Na Eziokwu: towards an understanding of Igbo traditional religious life and philosophy. Enugu: Pillar publishers.

Onwubiko, O. A. (1991) African thought, religion and culture. Enugu: SNAAP Press Ltd.

Onwunaeme, J. K. (2001) Christianity, culture and history in Akpo. Onitsha: Nkpor Printers.

Onyebuchi, C. O. (2010) The history of Ekeakpara and culture. Lagos: Oludare Limited.

Onyebueke, C. B. (1996) Christianity and Anambra culture. Onitsha: Ugo Printing Press Co.

Onyeike, G. O. (2000) The history of Akpo town. Enugu: Donklin Printers.

Quarcoopome, T. N. O. (1987) West African traditional religion. Ibadan: African Universities Press.

Ugwu, C. O. T. and L. E. Ugwueye (2004) African traditional religion. Prolegomenon, Lagos: Merit International Publications. 


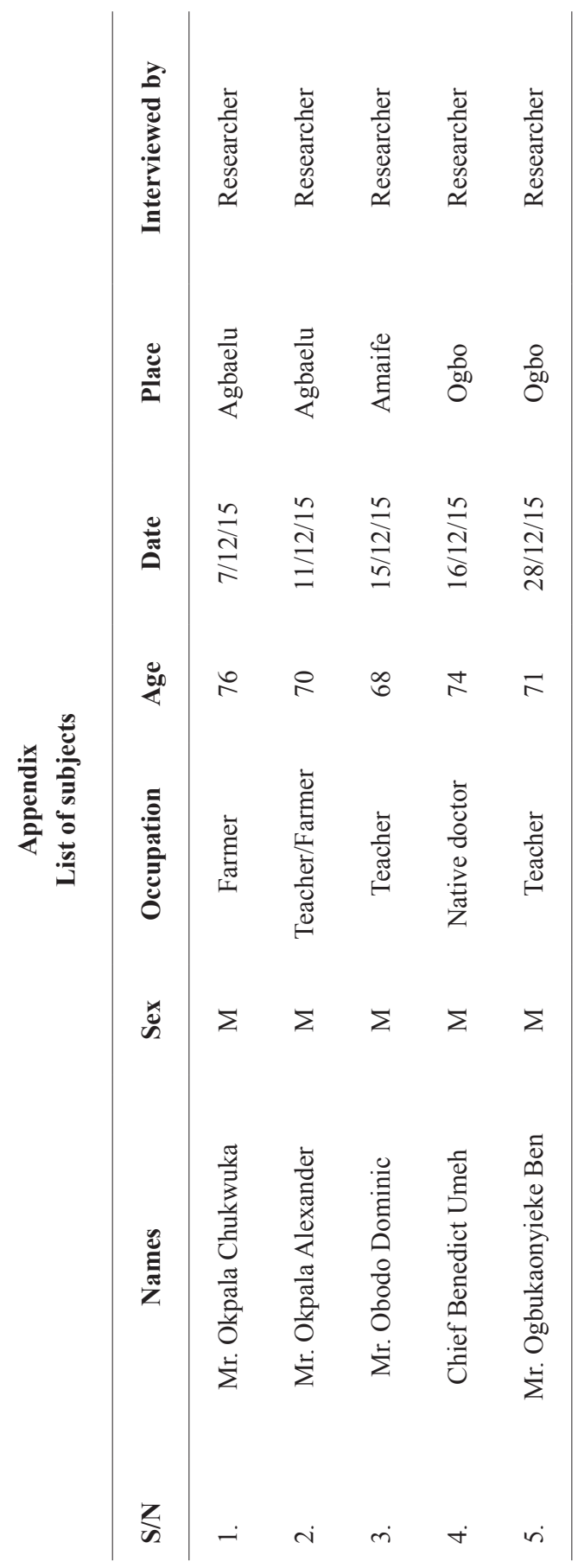

